\title{
PENDATAAN PENYANDANG MASALAH KESEJAHTERAAN SOSIAL (PMKS) BERBASIS WEB
}

\author{
Salman Suleman ${ }^{1}$,Roys Pakaya ${ }^{2}$, Yusni Daud ${ }^{3}$ \\ mail:1 salman@poligon.ac.id, ${ }^{2}$ roys@poligon.ac.id,23yusni.mhs16@ti.poligon.ac.id
}

1,2, 3 Prodi D3 Teknik Informatika Politeknik Gorontalo,

\begin{abstract}
Abstrak - Data Penyandang Masalah Kesejahteraan Sosial menurut jenis permasalahan merupakan data yang menjabarkan/mewujudkan mereka yang memiliki kehidupan yang tidak layak secara kemanusiaan dan memiliki kriteria masalah sosial yang meliputi kemiskinaen,ketelantaran, kecacatan, keterpencilan, ketunaan sosial dan penyimpangan perilaku, korban bencana dan korban tindak kekerasan, eksploitasi, dan diskriminasi.[1]

Dalam menjalankan fungsinya tersebut,Dinas Sosial Kabupaten Gorontalo belum memaksimalkan pemanfaatan teknologi informasi yang dapat mendukung kinerja terutama dalam penyajian informasi serta pembuatan database terpusat tentang penyandang masalah kesejahteraan sosial yang nantinya diharapkan dapat meminimalkan kesalahan yang mungkin terjadi dan dapat memberikan laporan secara cepat dan tepat.

Berdasarkan uraian di atas serta manfaat yang besar dari sistem informasi Peyandang Masalah Kesejahteraan Sosial untuk membantu instansi pemerintah dalam menghitung angka sebaran penduduk yang mengalami masalah sosial dalam suatu wilayah (kecamatan, desa) secara detail maka penulis mencoba merancang dan membuat suatu sistem informasi berbasis Web dengan judul "Pendataan Penyandang Masalah Kesejahteraan Sosial (PMKS) Pada Dinas Sosial Kabupaten Gorontalo".
\end{abstract}

Abstract - Data on Persons with Social Welfare Problems according to the type of problem is data that describes / manifests those who have a life that is not humanly feasible and has criteria for social problems which include poverty,neglect, disability, remoteness, social disability and behavior deviation, disaster victims and victims of violence.[1]

In carrying its functions,the Gorontalo District Social Service information technology support performance,especially in the presentation of information and the persons with social welfare problems expected to errors and be able to provide reports quickly and accurately.

Based the above description and the great benefits of Peyandang's information system, Social Welfare Issues to help government agencies in calculating the distribution of population experiencing social problems in a region (sub-district, village) in detail, the writer tries to design and create a Web-based information system with the title "Data Collection of Persons with Social Welfare Problems (PMKS) in Gorontalo District Social Service".

Kata Kunci : Web, Pendataan, PMKS.

\section{PENDAHULUAN}

Latar belakang

Kemudian seiring dengan perkembangan jaman yang serba modern, dan semakin majunya teknologi informasi sekarang ini telah menciptakan persaingan yang semakin ketat hampir diseluruh aspek kehidupan. Hal ini mengakibatkan kebutuhan masyarakat akan kemudahan proses pada segala bidang kerja semakin meningkat. Sehingga hampir semua pekerjaan dapat menghemat waktu, tenaga dan biaya Pengelolahan data menjadi informasi inilah yang dijadikan sebagai salah satu kelebihan dari komputer. Komputer telah merabah ke dalam satu instansi ke instansi yang lain. Dalam setiap instansi selalu membutuhkan sistem untuk mengumpulkan, mengolah, menyimpan melihat kembali dan menyalurkan informasi. Seperti hal-nya yang dilakukan oleh Dinas Sosial Kabupaten Gorontalo dalam menangani masalah kesejahteraan sosial khususnya di Kabupaten Gorontalo.

Dinas Sosial Kabupaten Gorontalo merupakan unsur pelaksana Pemerintah Daerah Kabupaten Gorontalo yang mempunyai tugas melaksanakan sebagian tugas umum pemerintah di Bidang Kesejahteraan Sosial. Salah satu tujuan dari dibentuknya Dinas Sosial Kabupaten Gorontalo adalah meningkatkan upaya perlindungan, rehabilitasi, dan pemberdayaan sosial bagi Penyandang Masalah Kesejahteraan Sosial (PMKS).[1]

Data Penyandang Masalah Kesejahteraan Sosial menurut jenis permasalahan merupakan data yang menjabarkan/mewujudkan mereka yang memiliki kehidupan yang tidak layak secara kemanusiaan dan memiliki kriteria masalah sosial yang meliputi kemiskinan, ketelantaran, kecacatan, keterpencilan, ketunaan sosial dan penyimpangan perilaku, korban bencana dan korban tindak kekerasan, eksploitasi, dan diskriminasi. Sebagai Instansi pemerintah pada tingkat kabupaten, Dinas Sosial merupakan instansi dengan tugas pokok dan fungsi melakukan pendataan, pengolahan data dan pelayanan terhadap masyarakat yang mengalami masalah sosial sesuai dengan peraturan yang berlaku.[2]

Dalam menjalankan fungsinya tersebut, Dinas Sosial Kabupaten Gorontalo belum memaksimalkan pemanfaatan kerja dari petugas baik dari segi pendataan karena petugas masih menggunakan proses kerja yang masih menggunakan cara manual untuk mendapatkan data dari penduduk tersebut. Kemudian Dinas Sosial Kabupaten Gorontalo juga belum memaksimalkan pemanfaatan teknologi informasi yang dapat mendukung kinerja terutama dalam penyajian informasi serta pembuatan database terpusat tentang penyandang masalah kesejahteraan sosial yang nantinya diharapkan dapat meminimalkan kesalahan yang mungkin terjadi dan dapat memberikan laporan secara cepat dan tepat.

Berdasarkan uraian di atas serta manfaat yang besar dari sistem informasi Peyandang Masalah Kesejahteraan Sosial untuk membantu instansi pemerintah dalam menghitung angka sebaran penduduk yang mengalami masalah sosial dalam suatu wilayah (kecamatan, desa) secara detail maka penulis mencoba merancang dan membuat suatu sistem informasi berbasis web dengan judul "Aplikasi Pendataan Penyandang Masalah Kesejahteraan Sosial Berbasis web Pada Dinas Sosial Kabupaten Gorontalo". Karena penulis berharap dengan adanya sistem informasi ini dapat mempermudah proses kerja dari Petugas Desa, 
Petugas Dinas Sosial Kabupaten Gorontalo dalam mendapatkan data tentang penduduk yang berstatus sebagai Penyandang Masalah Kesejahteraan Sosial (PMKS) tersebut.

\section{A. Rumusan masalah}

Berdasarkan latar belakang yang telah disebutkan di atas, maka masalah dalam penelitian ini adalah bagaimana mengetahui berapa banyak penduduk yang berstatus sebagai penyandang masalah kesejahteraan sosial pada Dinas Sosial Kabupaten Gorontalo?

\section{B. Batasan}

Pada Aplikasi Sistem Informasi Penyandang Masalah Kesejahteraan Sosial ini membahas terbatas pada beberapa bagian :

1. Perancangan aplikasi ini hanya untuk perangkat berbasis web.

2. Dari 21 Jenis Penyandang Masalah Kesejahteraan Sosial, Hanya mengambil dua masalah yaitu tentang Balita Terlantar, fakir miskin sehingga menjadi optimal dan terkontrol dalam pelaksanaannya.

3. Untuk mengukur efisiensi dan efektivitas dari kinerja sistem baru yang akan dibuat, serta membandingkan dengan sistem yang telah ada.

\section{Tujuan}

Adapun tujuan dari penelitian ini adalah sebagai berikut:

1. Untuk membantu mengetahui data penduduk yang berstatus sebagai penyandang masalah kesejahteraan sosial.

2. Diharapkan Dapat membantu mempermudah kecamatan untuk mendapatkan data dan pengolahan data untuk penduduk dengan status sebagai penyandang masalah kesejahtraan sosial.

\section{Manfaat}

1. Untuk Dinas Sosial Kabupaten Gorontalo dalam penyajian informasi serta pembuatan database yang terpusat tentang penyandang masalah kesejahteraan sosial

2. Untuk Petugas/Pendamping yaitu memberikan kemudahan dalam mendapatkan informasi yang dibutuhkan untuk data masyarakat sebagai penyandang masalah kesejahtraan sosial pada kecamatan tersebut.

3. Untuk penduduk diharapkan dapat membantu proses pendataan pada penduduk tersebut.

\section{KAJIAN PUSTAKA}

\section{A. Penelitian Terdahulu}

Dasar atau acuan yang diperoleh dari penelitian sebelumnya merupakan hal yang sangat penting karena dapat membantu dalam pemecahan masalah sehingga dapat menjadi data pendukung dalam penelitian. Adapun beberapa penelitian yang menjadi perbandingan yang tidak terlepas dari tema penelitian, sebagai berikut:

1. Pada jurnal “Analisis dan Implementasi sistem informasi pendataan penyandang masalah kesejahteraan sosial(pmks) di dinas sosial dan tenaga kerja kota pangkal pinang menggunakan aplikasi desktop berbasis java.[3]" pada jurnal ini dijelaskan bagaimana cara dalam menyajikan laporan dengan penggunaan komputer hanya sebatas pengetikan seluruh data PMKS yang telah dipersiapkan sebelumnya dengan menggunakan aplikasi Ms-Excel, sehingga dalam menghasilkan laporan seluruh laporan yang akurat dan tepat relatif lama. Maka Perlu pengembangan berkelanjutan sesuai dengan kemajuan teknologi informasi sehingga aplikasi sistem informasi akan semakin berdaya dan berfungsi seiring dengan kebijakan-kebijakan serta aturan-aturan baru. Kemudian berbedaan antara jurnal yang telah di baca ini dengan aplikasi ini yaitu dalam melakukan pendataan dan penginputan data penyandang masalah kesejahteraan sosial(pmks) ini petugas dapat menggunakan aplikasi dengan mudah dan dapat mempermudah proses kerja dari petugas tersebut.

2. "Perancangan sistem informasi berbasis web data pmks (penyandang masalah kesejahteraan sosial) pada ikatan pekerja sosial masyarakat kabupaten pelalawan.[4]" Pada jurnal ini membahas bagaimana memperoleh informasi bahwa data PMKS yang dikumpulkan oleh PSM harus dikirim ke sekretariat IPSM agar data dapat divalidasi. Dari penjelasan tersebut dapat dilihat bahwa sistem ini berbeda dengan sistem yang telah dibuat. Pada sistem yang telah dibuat oleh penulis akan menampikan proses pendataan, informasi dari pendataan tersebut. Namun pada jurnal ini tidak menjelaskan bagaiman proses PSM maupun IPSM mendapatkan data dan proses pendataan-Nya tersebut.

3. "Pengelompokan data pmks menggunakan metode self organizing." banyaknya penyandang masalah kesejahteraaan sosial. Saat ini pembangunan ekonomi nasional masih belum mampu meningkatkan kesejahteraan rakyat secara luas. 
Indikator utamanya adalah tingginya ketimpangan dan kemiskinan. Angka kemiskinan ini akan lebih besar lagi jika dalam kategori kemiskinan dimasukkan jumlah PMKS. Pengelompokan variabel PMKS kemudian divisualisasikan kedalam Peta DIY. Namun pada aplikasi yang telah dikerjakan oleh penulis untuk pendataan penyandang masalah kesejahteraan sosial(pmks) lebih mudah dengan menggunakan sistem berbasis web".

Penyandang Masalah Kesejahteraan Sosial

Penyandang Masalah Kesejahteraan Social (PMKS) adalah seseorang atau keluarga yang mengalami suatu hambatan, kesulitan atau gangguan dalam melaksanakan fungsi sosialnya dan tidak dapat menjalin hubungan yang serasi dan kreatif dilingkungannya sehingga tidak memenuhi kebutuhan hidupnya (jasmani, rohani,dan social) secara memadai dan wajar.

Kesejahteraan sosial merupakan suatu keadaan terpenuhinya kebutuhan hidup yang layak bagi masyarakat sehingga mampu mengembangkan diri dan dapat melaksanakan fungsi sosialnya yang dapat dilakukan pemerintah, pemerintah daerah dan masyarakat dalam bentuk pelayanan sosial yang meluputi rehabilitasi sosial, jaminan sosial, pemberdayaan sosial, dan perlindungan sosial. Hal ini membuat pihak pemerintah membuat program dengan istilah Penyandang Masalah Kesejahteraan Sosial(PMKS) yang terdiri dari beberapa masalah yang ada di Indonesia.[5]

\section{METODOLOGI PENELITIAN}

\section{A. Analisis Data}

Dinas Sosial merupakan instansi dengan tugas pokok dan fungsi melakukan pendataan, pengolahan data dan pelayanan terhadap masyarakat yang mengalami masalah sosial sesuai dengan peraturan yang berlaku. Penelitian ini hanya difokuskan untuk pendataan pada Dinas Sosial Kabupaten Gorontalo.

Kemudian untuk mendapatkan data yang dibutuhkan, penulis melakukan analisis dan mengolah data yang telah dikumpulkan dengan metode yang telah ditentukan.dengan menggunakan metode observasi dan wawancara dengan pegawai atau petugas yang berada di kantor dinas sosial Kabupaten Gorontalo khususnya pada bagian Penyandang Masalah Kesejahteraan Sosial (PMKS). Kemudian pada Kecamatan Mootilango melakukan wawancara dengan Bapak Eman Ajilahu selaku pendamping yang berada di Kecamatan Mootilango, sehingga memperoleh informasi yang terperinci.

\section{B. Analisis Sistem Berjalan}

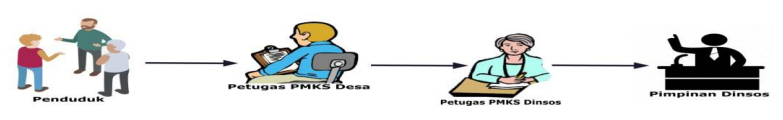

Gambar.1 Sistem Berjalan Pendataan PMKS

Deskripsi rancangan pendataan penduduk Penyandang Masalah Kesejahteraan Sosial (PMKS) yang sedang berjalan saat ini di kantor Dinas Sosial, Kabupaten Gorontalo. Berdasarkan hasil wawancara dengan pegawai dinas sosial maka terdapat prosedur yang terlibat dalam sistem informasi yang akan dibangun, diantaranya :

Menggunakan cara manual untuk mendapatkan data dari penduduk tersebut, Petugas PMKS Desa melakukan pendataan kepada penduduk yang berstatus penyandang masalah kesejahteraan sosial (PMKS). Petugas PMKS Desa melakukan pendataan penyandang masalah kesejahteraan sosial (PMKS) melalui dokumen pendataan PMKS, setelah itu data tersebut dimasukan kepada Petugas PMKS Dinsos untuk dilihat serta akan dilakukan verifikasi data tersebut. kemudian Pimpinan Dinsos melihat informasi dari hasil pendataan yang telah di masukan.Perancangan Sistem 


\section{Analisis Sistem}
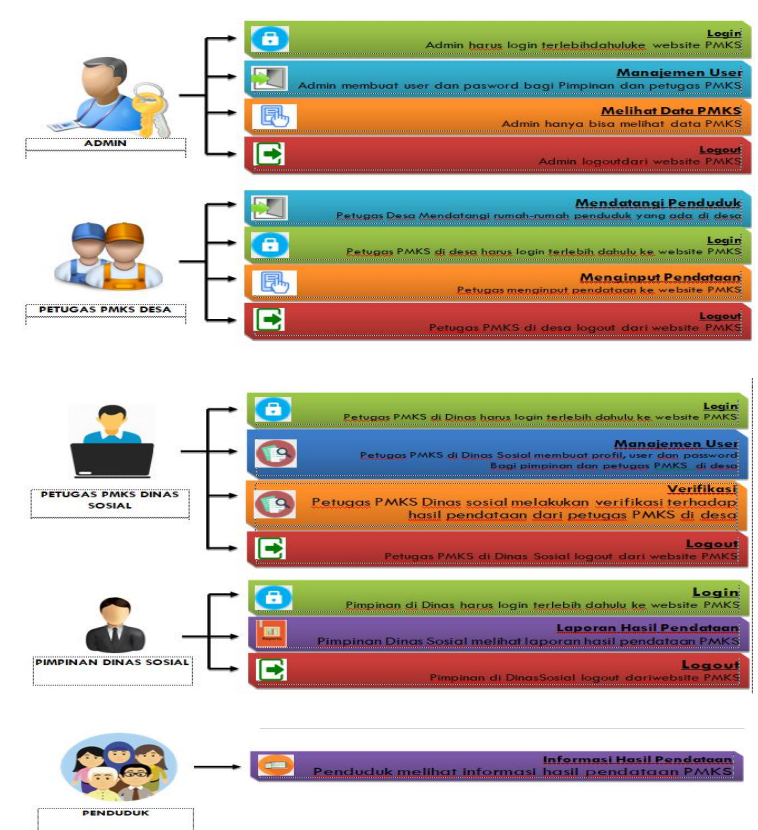

Gambar.2 Sistem Usulan Pendataan PMKS

Deskripsi rancangan system Pendataan Penyandang Masalah Kesejahteraan Sosial (PMKS) yang akan diajukan dengan menampilkan system yang telah dikerjakan berbasis web, petugas yang berada di desa melakukan login terlebih dahulu setelah itu, petugas melakukan penginputan hasil dari pendataan penduduk penyandang masalah kesejahteraan sosial (PMKS) melalui website pendataan penyandang masalah kesejahteraan sosial (PMKS), setelah data tersebut di inputkan oleh petugas yang di desa maka tugas dari petugas dinas sosial yang akan memverifikasi data yang telah diterimah. Kemudian pimpinan yang berada di kantor dinas sosial kabupaten gorontalo dapat melihat informasi pendataan yang telah di inputkan oleh petugas tersebut. Kemudian penduduk melihat informasi hasil pendataan penyandang masalah kesejahteraan sosial (PMKS) pada website.

\section{Rancangan Sistem}

Dalam pembuatan website tentang pendataan penyandang masalah kesejahteraan sosial (PMKS) penulis menggunakan rancangan system menggunakan uml sebagai berikut:

\section{E. Use Case Diagram}

Use case dibawah ini merupakan penjelasan fungsional keselurahan dari pendataan penyandang masalah kesejahteraan sosial (PMKS) berbasis web yang akan dibangun.

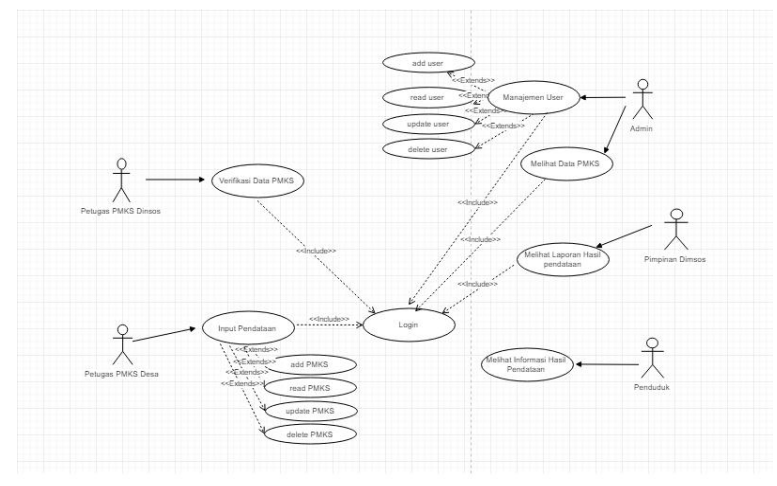

Gambar.3 Use Case pendataan Data PMKS 
Adapun deskripsi fungsional dari masing-masinh use case diagram keseluruhan adalah sebagai berikut :

Tabel.1 Use Case Diagram

\begin{tabular}{|l|c|l|}
\hline No & Use Case & \multicolumn{1}{|c|}{ Deskripsi } \\
\hline 1 & Login & $\begin{array}{l}\text { Merupakan use case login untuk } \\
\text { petugas pmks desa, petugas pmks } \\
\text { dinsos dan pimpinan dinsos. }\end{array}$ \\
\hline 2 & Tambah pmks & $\begin{array}{l}\text { Merupakan use case untuk } \\
\text { menambahkan data tentang pmks. }\end{array}$ \\
\hline 3 & Edit pmks & $\begin{array}{l}\text { Merupakan use case untuk dapat } \\
\text { mengedit data pmks, jika ada data yang } \\
\text { berubah dari hasil pendataan. }\end{array}$ \\
\hline 4 & Lihat pmks & $\begin{array}{l}\text { Merupakan use case untuk dapat } \\
\text { melihat data pmks, dari hasil pendataan. }\end{array}$ \\
\hline 5 & Hapus pmks & $\begin{array}{l}\text { Merupakan use case untuk dapat } \\
\text { menghapus data pmks, jika ada data } \\
\text { yang tidak digunakan lagi }\end{array}$ \\
\hline 6 & Informasi & $\begin{array}{l}\text { Merupakan use case untuk } \\
\text { menampilkan Informasi dari hasil } \\
\text { pendataan pmks yang dapat dilihat oleh } \\
\text { pimpinan dinsos, petugas pmks desa, } \\
\text { petugas pmks dinsos dan penduduk. }\end{array}$ \\
\hline 7 & Verifikasi & $\begin{array}{l}\text { Merupakan use case untuk } \\
\text { menampilkan verifikasi data kepada } \\
\text { petugas pmks dinsos, setelah petugas } \\
\text { pmks desa mengirimkan data tersebut. }\end{array}$ \\
\hline 8 & Logout & $\begin{array}{l}\text { Merupakan } \text { usa case untuk } \\
\text { penghapusan sesi user. }\end{array}$ \\
\hline
\end{tabular}

\section{F. Class Diagram}

Class diagram menggambarkan struktur statis dari kelas dalam sistem anda dan menggambarkan atribut, operasi dan hubungan antara kelas. Class diagram membantu dalam memvisualisasikan struktur kelas-kelas dari suatu sistem dan merupakan tipe diagram yang paling banyak dipakai. Selama tahap desain, class diagram berperan dalam menangkap struktur dari semua kelas yang membentuk arsitektur sistem yang dibuat.

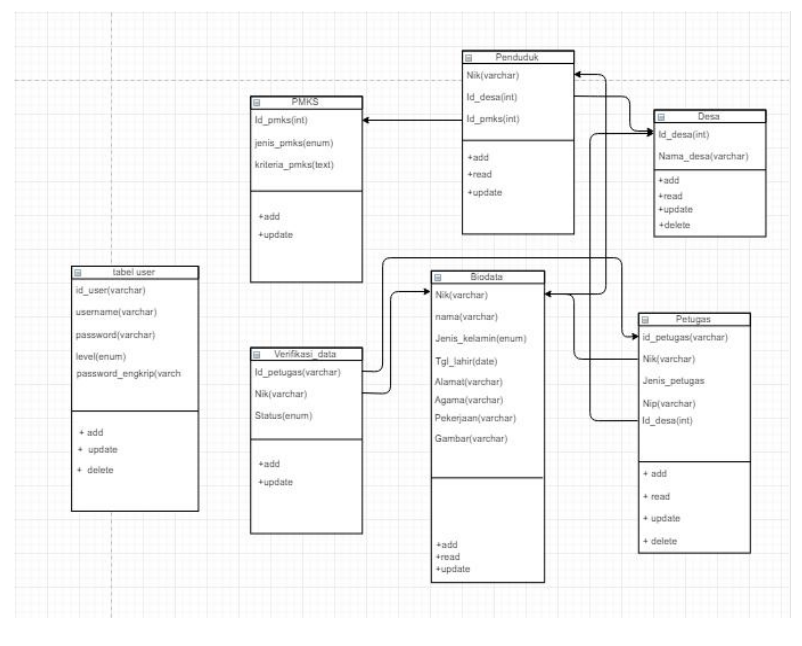

GAMBAR.4 CLASS DIAGRAM PENDATAAN PMKS 


\section{IMPLEMENTASI}

\section{A. Hasil Penelitian}

Setelah sistem dianalisis dan di desain secara rinci, maka akan dilanjutkan ketahap implementasi yang menerapkan hasil analisis sistem kesebuah aplikasi. Implementasi sistem merupakan kumpulan dari elemen-elemen yang telah di desain ke dalam bentuk pemrograman untuk menghasilkan suatu tujuan yang dibuat berdasarkan kebutuhan.

\section{B. Menu Utama Aplikasi}

Menu utama pada aplikasi ini adalah berupa tampilan Dashboard yang terdiri dari Halaman Utama, yang menampilkan informasi dari hasil pendataan penyandang masalah kesejahteraan sosial(PMKS) agar dapat dilihat oleh penduduk.

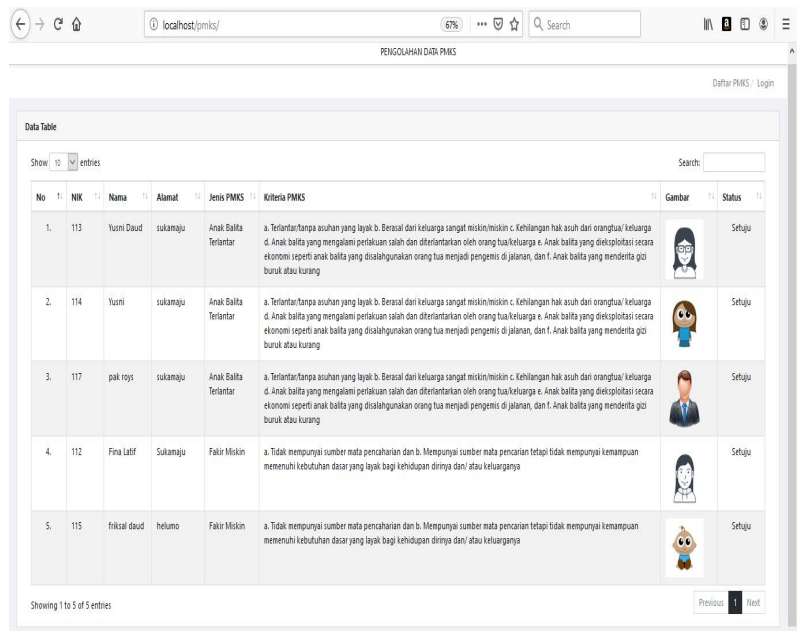

Gambar.5 Menu Utama/ Halaman Penduduk

\section{Keterangan :}

Pada tampilan ini, penduduk dapat melihat informasi dari hasil pendataan yang dilakukan oleh petugas Penyandang Masalah Kesejahteraan Sosial(PMKS) yang berada di desanya tersebut kemudian di verifikasi oleh petugas yang berada di Dinas Sosial, maka penduduk dapat melihat apakah dirinya sudah terdata dalam Penduduk Penyandang Masalah Kesejahteraan Sosial(PMKS) dan jika sudah terdata maka penduduk dapat melihat status apakah di Setujui oleh petugas Dinas Sosial atau Tidak Disetujui .

\section{Tampilan Admin}

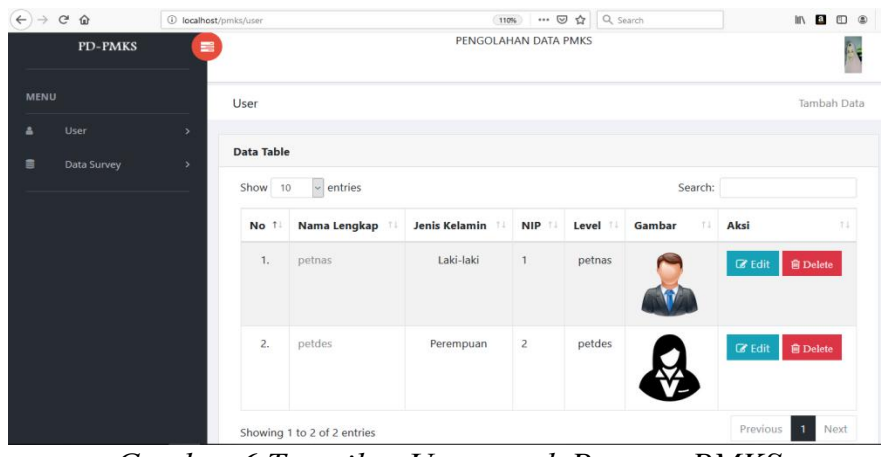

Gambar.6 Tampilan User untuk Petugas PMKS 


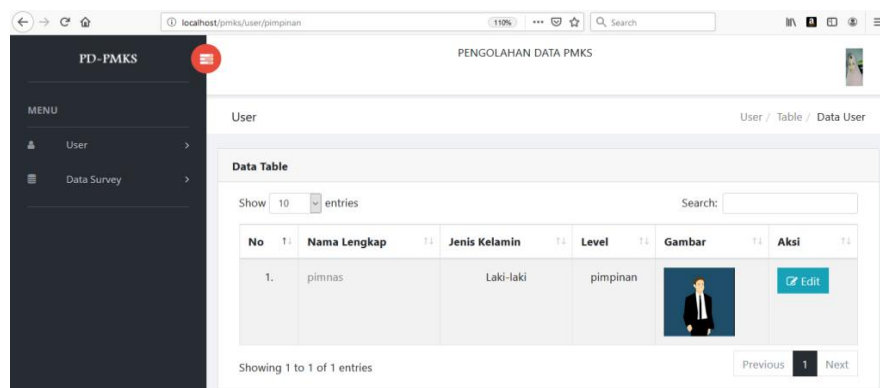

Gambar.7 Tampilan User untuk Pimpinan Dinsos

\section{Keterangan :}

Ini adalah tampilan yang dapat di akses oleh admin, tampilan ini admin gunakan untuk dapat menambahkan User, mengedit user dan menghapus user pada aplikasi tersebut. Kemudian tampilan ini menampilkan user-user apa saja yang terhubung dan dapat mengakses aplikasi ini .

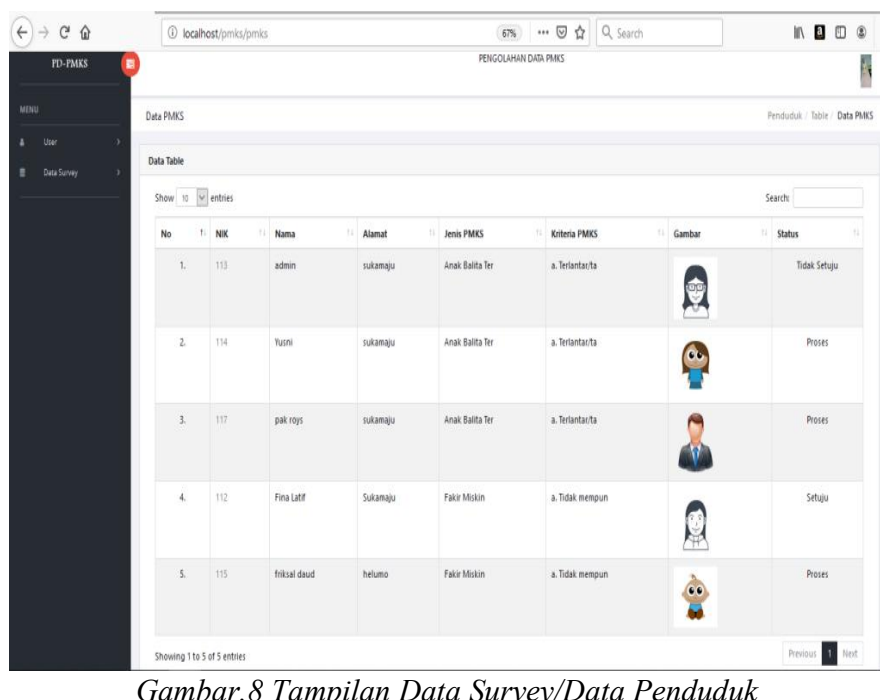

\section{Keterangan :}

Kemudian tampilan ini juga yang dapat di akses oleh admin, tampilan ini gunakan untuk dapat melihat hasil dari pendataan yang telah di inputkan oleh petugas yang berada di desa dan data tersebut di verifikasi oleh petugas yang berada di dinas sosial yang dilihat dari status penduduk tersebut.

\section{Tampilan Petugas PMKS Dinas Sosial}

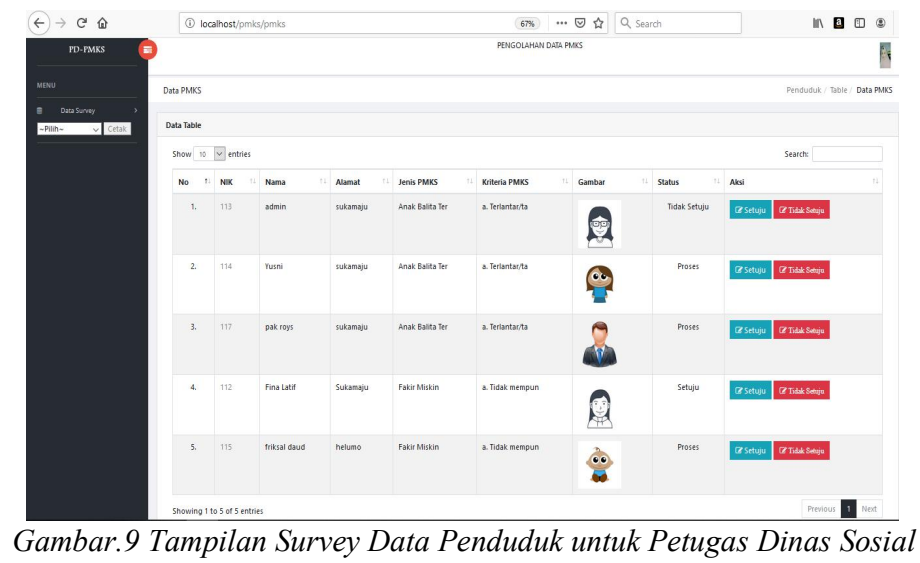



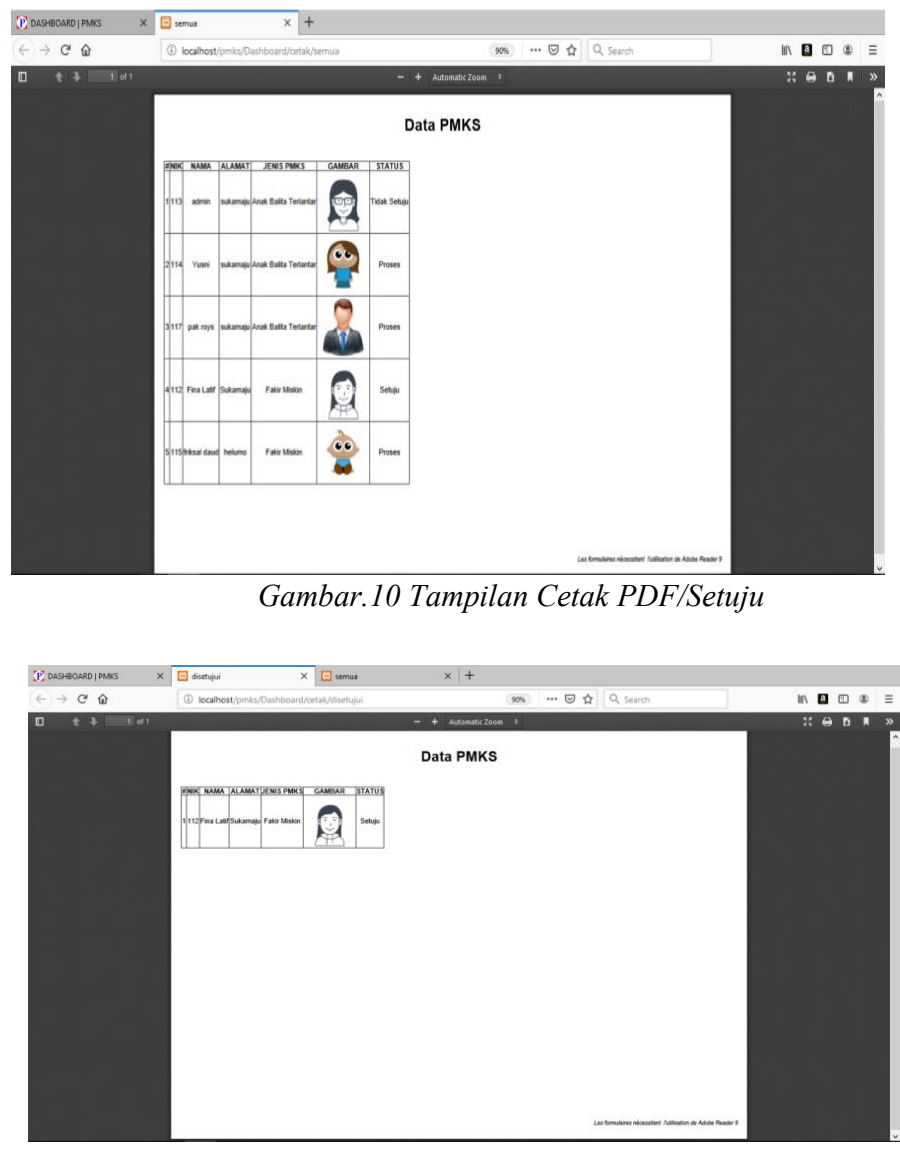

Gambar.11 Tampilan Cetak PDF/Setuju

Keterangan :

Ini adalah tampilan yang dapat di akses oleh Petugas PMKS yang berada di Dinas Sosial, tampilan ini digunakan untuk dapat melihat data penduduk yang telah di inputkan oleh petugas PMKS yang berada di Desa. Kemudian Petugas PMKS Dinas Sosial akan melakukan verifikasi data terhadap data yang yang telah di inputkan. Verifikasi tersebut digunakan untuk dapat merubah status dari data penduduk tersebut. Data penduduk dengan status proses yang akan di rubah menjadi setuju atau data tidak setuju. Kemudian petugas pmks dinas sosial juga dapat melakukan pencetakan file status setuju, tidak setuju dan semua data dengan format pdf.

\section{E. Tampilan Petugas PMKS Desa}

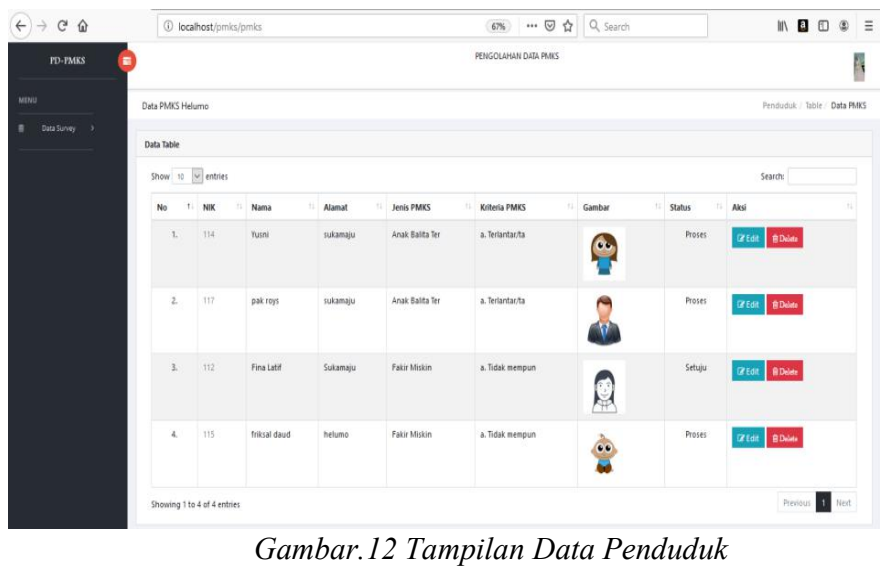

Keterangan :

Ini adalah tampilan yang dapat di akses oleh Petugas PMKS yang berada di Desa, tampilan ini digunakan untuk dapat melihat data penduduk yang telah di inputkan oleh petugas PMKS itu sendiri. Kemudian pada tampilan ini petugas dapat melakukan aksi mengedit, menghapus data sesuai dengan keperluan petugas. 


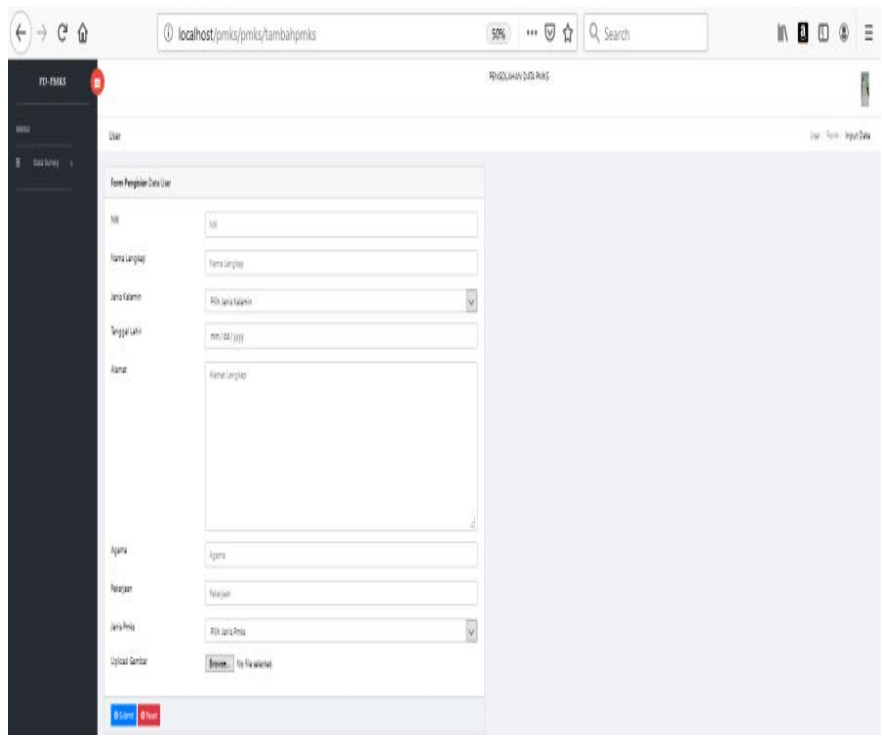

Gambar.13 Tampilan Tambah Data Penduduk

\section{Keterangan :}

Tampilan ini dapat di akses oleh Petugas PMKS yang berada di Desa, tampilan ini digunakan untuk dapat menambahkan data penduduk yang belum di inputkan oleh petugas PMKS itu sendiri. Dan jika data penduduk tersebut sudah di inputkan maka akan muncul informasi bahwa data ini sudah terdaftar atau sudah digunakan.

\section{F. Tampilan Pimpinan Dinas Sosial}

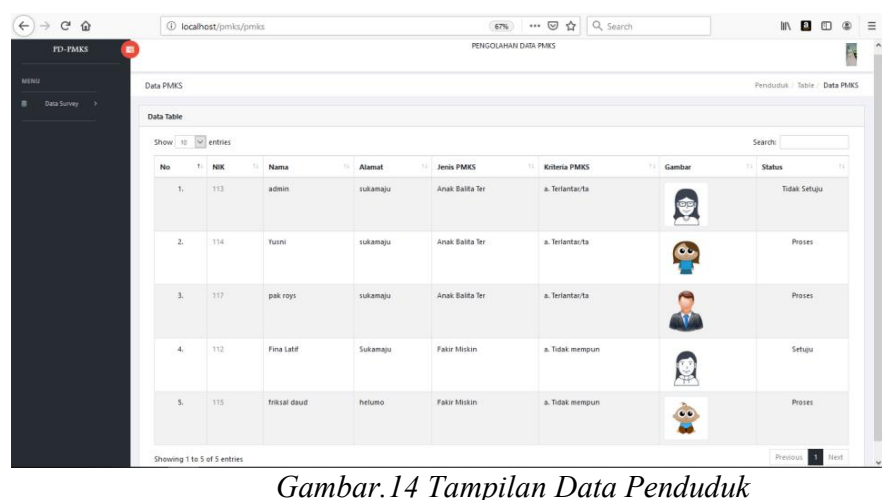

Keterangan :

Tampilan ini hanya dapat di akses oleh pimpina dinas sosial, tampilan ini gunakan untuk dapat melihat informasi dari hasil pendataan yang telah di inputkan oleh petugas yang berada di desa dan data tersebut di verifikasi oleh petugas yang berada di dinas sosial.

\section{PENUTUP}

\section{A. Kesimpulan}

Dari uraian yang telah dikemukakan pada Proyek Akhir ini, dapat diambil kesimpulan sebagai berikut :

1. Informasi yang ditampilkan pada sistem Informasi Pendataan Penduduk adalah informasi data penduduk yang berstatus sebagai penyandang masalah kesejahteraan sosial(pmks).

2. Dengan adanya sistem terkomputerisasi di Kantor Dinas Sosial Kabupaten Gorontalo, informasi tentang data penduduk dan proses pendataan penduduk dapat diperoleh dengan cepat dan akurat daripada sistem manual yang ada sebelumnya.

3. Dengan rancangan sistem yang dibuat sederhana, sistem ini dapat diterapkan pula di desa-desa lain, karena proses pendataan penduduk relatif sama.

\section{B. Saran}

Sistem ini memiliki beberapa kekurangan yang dapat dikembangkan untuk memperbaiki kinerja dari sistem ini. Oleh karena itu penulis menyampaikan : 
1. Diharapkan Sistem ini dapat membantu proses dari pendataan.

2. Diharapkan Sistem ini dapat dikembangkan baik dari segi sistem Web-nya maupun kearah aplikasi berbasis Android.

3. Selalu melakukan perubahan atau pengembangan terhadap sistem informasi pendataan sesuai dengan perkembangan zaman dan kebutuhan yang diinginkan.

\section{DAFTAR PUSTAKA}

[1] S. Kasus, D. Sosial, and K. Bandung, “Aplikasi Berbasis Web Penyandang Masalah Kesejahteraan Sosial Modul Dinas Sosial," vol. 4, no. 3, pp. 1369-1388, 2018.

[2] Muslim and H. Sismoro, "Perancangan Sistem Informasi Berbasis Web Data Pmks ( Penyandang Masalah Kesejahteraan Sosial ) Pada Ikatan Pekerja Sosial Masyarakat," vol. 15, no. 02, pp. 45-50, 2014.

[3] S. Pmks, D. I. Dinas, S. Dan, T. Kerja, and I. Luciawati, "PENDATAAN PENYANDANG MASALAH KESEJAHTERAAN KOTA PANGKALPINANG MENGGUNAKAN APLIKASI DESKTOP BERBASIS JAVA Keyword :," pp. 1-7.

[4] D. Provinsi and B. Sosial, "bphn.go.id," 2012.

[5] S. Kasus, D. Sosial, and K. Bandung, "Aplikasi Berbasis Web Penyandang Masalah Kesejahteraan Sosial Modul Desa dan Kecamatan," vol. 4, no. 3, pp. 1348-1368, 2018.

[6] R. V Palit, Y. D. Y. Rindengan, and A. S. M. Lumenta, "Rancangan Sistem Informasi Keuangan Berbasis Web Di Jemaat GMIM Bukit Moria Malalayang,” E-Journal Tek. Elektro dan Komput. vol, vol. 4, no. 7, pp. 1-7, 2015. 